Marcin Łysko

\title{
Prawo wykroczeń Niemieckiej Republiki Demokratycznej
}

Keywords: Petty offences, GDR

\section{Summary}

In 1949 the German Democratic Republic was established as a state. Petty offences' law in this country was gradually changed and it differed from old German model, in which petty offences were regulated in criminal code. Petty offences were treated as acts of minimal social danger and in 1968 they were finally excluded from penal law and formed an independent group of offences against social order. These offences were treated as a violation of social discipline and they hit state's administration and its planning functions. The jurisdiction in these matters was supposed to have only educational character, because penalties of arrest and of restricted liberty were eliminated. A big quantity of corrective measures was applied. The jurisdiction in these matters was transferred to the administrative organs, which activity was somehow connected with the committed petty offence. The procedure was of administrative character, there was no elements of principle of adversary trial system. In fact, these proceedings were of inquisitorial character. The courts of common law could not control these proceedings, you could only appeal to a higher instance of the administrative organ. After 1968, the new group of petty offences was created. It derived from former criminal code and consisted of several misdemeanors, which were nor longer treated as crimes (depenalization). From this time there were two groups of petty offences. Both of them characterized by minimal social danger and by punishment based on corrective measures. There were some differences, because the new group of offences was under jurisdiction of People's Police (Volkspolizei) and of special civic courts. You could appeal to court in these cases, which belonged to second group. It reminded a little of the old German model of petty offences' jurisdiction. Petty offences' law in GDR was different from this kind of law in other socialist countries, because it was concentrated on corrective measures, not on the repression. 
1. Powstała w 1949 r. na terenach radzieckiej strefy okupacyjnej Niemiecka Republika Demokratyczna (NRD) w celu zachowania pozorów kontynuacji państwowości republiki weimarskiej przejęła rozwiązania prawne z okresu poprzedzającego powstanie III Rzeszy. W dziedzinie prawa karnego oznaczało to obowiązywanie kodeksu karnego Rzeszy Niemieckiej z 1871 r., który wzorem francuskim przyjmował trójpodział przestępstw: na zbrodnie, występki i wykroczenia ${ }^{1}$. Określane mianem prawa karno-policyjnego wykroczenia traktowano na równi z pozostałymi czynami karalnymi. Wychodzono bowiem z założenia, że nie ma różnic jakościowych między przestępstwem kryminalnym a naruszeniem przepisów porządkowo-administracyjnych. Objęcie prawa karno-policyjnego zakresem regulacji kodeksu karnego skutkowało poddaniem wykroczeń tym samym regułom odpowiedzialności co pozostałych przestępstw i uznaniem orzecznictwa w sprawach wykroczeń za wymiar sprawiedliwości. Jednakże celem odciążenia sądów od rozpatrywania dużej liczby spraw o wykroczenia przekazano organom administracji prawo wykonywania zastępczego wymiaru sprawiedliwości. Nakładanie kar na obywateli nie stanowiło samodzielnej kompetencji aparatu administracyjnego, lecz miało charakter orzecznictwa karno-administracyjnego, wykonywanego w zastępstwie sądu za zgodą obwinionego ${ }^{2}$. Obwiniony mógł zażądać przekazania sprawy na drogę postępowania sądowego przed wydaniem orzeczenia, wyłączając tym samym kompetencje organu administracji w sprawie o wykroczenie. Jeżeli nawet obwiniony nie wyraził sprzeciwu co do rozpatrzenia jego sprawy przez organ administracji, to mógł wydane $\mathrm{w}$ sprawie orzeczenie zakwestionować, zgłaszając żądanie przekazania sprawy na drogę postępowania sądowego. Orzeczenie władzy administracyjnej nie było wiążące dla sądu, gdyż postępowanie $\mathrm{w}$ sprawach o wykroczenia wszczynano $\mathrm{w}$ wyniku wniesienia aktu oskarżenia przez prokuratora i miało ono charakter kontradyktoryjny ${ }^{3}$. W systemie niemieckim orzecznictwo karno-administracyjne traktowano zatem jako wymiar sprawiedliwości należący do sądów, w zastępstwie których w pierwszej instancji mógł orzekać organ administracji wyłącznie za zgodą ukaranego. Traktowanie prawa karno-policyjnego jako integralnej części prawa karnego nie stało na przeszkodzie w praktyce wydawania ustaw pozakodeksowych zawierających normy o charakterze blankietowym, chociaż praktyka ta była sprzeczna z zasadą nulla poena sine lege poenali anteriori. Zawarte w nich było upoważnienie organów ad-

\footnotetext{
${ }^{1}$ K. Sójka-Zielińska, Historia prawa, wyd. X, Warszawa 2007, s. 294.

2 M. Zimmermann, Orzecznictwo karno-administracyjne, „Zagadnienia Karno-Administracyjne” 1965, nr 4, s. 6.

3 W. F. Dąbrowski, Zagadnienia ogólne orzecznictwa karno-administracyjnego w PRL, Poznań 1970, s. 20 .
} 
ministracji do określenia w drodze rozporządzeń wysokości kar za poszczególne wykroczenia w granicach określonych przepisami kodeksu karnego ${ }^{4}$.

Wydawanie ustaw blankietowych, których postanowienia konkretyzowały organy administracji państwowej w drodze rozporządzeń, doprowadziło do powstania licznej grupy wykroczeń pozakodeksowych o mniejszym ciężarze gatunkowym. Istota tych wykroczeń polegała na naruszeniu przepisów porządkowych wydawanych przez organy administracji. Nie miały one charakteru bezprawia kryminalnego, stąd zaczęto je określać mianem wykroczeń porządkowych. Stopniowe wykształcanie się grupy wykroczeń porządkowych, występujących obok dotychczasowych wykroczeń prawnokarnych, nie pociągnęło za sobą odmiennego ukształtowania zasad odpowiedzialności i trybu orzekania w zależności od rodzaju wykroczenia 5 .

Zapoczątkowany w czasach II Rzeszy proces wyodrębniania prawa wykroczeń w samodzielną grupę czynów karalnych przybierze na sile wraz z powstaniem NRD. W pierwszych latach państwowości wschodnioniemieckiej (1950-1951) upoważniono organy administracji do wymierzania kar grzywny za wykroczenia popełniane w związku z wykonywanymi przez nie zadaniami. Prawo wymierzania kar uzyskali minister i wiceminister spraw wewnętrznych, przewodniczący prezydiów rad terenowych ${ }^{6}$ oraz kierownicy terenowych organów administracji specjalnej. Kompetencje karno-administracyjne terenowych organów administracji miały związek z ich działalnością w zakresie zdrowia, weterynarii, budownictwa i gospodarki narodowej. Kary orzekane przez te organy mogły być kwestionowane przez ukaranego jedynie w drodze wniesienia odwołania do organu wyższego szczebla, gdyż nie przewidziano możliwości skierowania sprawy na drogę postępowania sądowego ${ }^{7}$. To sprzeczne z założeniami niemieckiego systemu orzecznictwa karno-administracyjnego rozwiązanie będzie stopniowo rozszerzane na kolejne grupy wykroczeń związanych z funkcjonowaniem aparatu administracji państwowej i będzie stanowiło jedną z cech wyróżniających wykroczenia porządkowe od pozostałych czynów karalnych.

Przyznanie organom administracji prawa nakładania kar za wykroczenia porządkowe miało miejsce kosztem ich kompetencji karno-administracyjnych w zakresie tradycyjnych wykroczeń, które w 1952 r. zostały przekazane orzecznictwu Policji Ludowej NRD. Funkcjonariusze policji mogli ukarać sprawcę wy-

4 M. Zimmermann, Art. 72 Konstytucji a dotychczasowe ustawodawstwo polskie, Lwów 1930, s. $84-85$.

${ }^{5}$ Ibidem, s. 86-87.

${ }^{6} \mathrm{~W}$ ustawodawstwie NRD terenowe organy władzy państwowej nosiły nazwę „terenowe przedstawicielstwa ludowe”, natomiast ich organy zarządzająco-wykonawcze określano mianem „rad terenowych". Rady terenowe stanowily odpowiednik polskich prezydiów rad narodowych sprzed reformy administracji terenowej w 1972 i 1973 r.

Orzecznictwo za granica. W Niemieckiej Republice Demokratycznej, „Zagadnienia Karno-Administracyjne" 1961, nr 3, s. 59. 
kroczenia w trybie mandatowym, jeżeli jednak doszli do wniosku że ze względu na wagę czynu należy wymierzyć karę powyżej granicy przewidzianej w postępowaniu mandatowym, to przedkładali sprawę komendantowi powiatowemu. Był on upoważniony do osobistego orzekania kar grzywny w trybie karno-administracyjnym w granicach do 150 marek. Od orzeczenia komendanta powiatowego policji ukarany miał prawo złożyć zażalenie albo do komendanta wojewódzkiego, albo do sądu. Zażalenie było wnoszone do tego samego komendanta, który wydał orzeczenie, celem ponownego zbadania sprawy i ewentualnej zmiany lub uchylenia wymierzonej kary. W przypadku utrzymania kary zażalenie było kierowane na ręce komendanta wojewódzkiego policji, który podejmował ostateczną decyzję co do wymiaru kary. Wobec obowiązywania zakazu reformationis in peius, mógł on jedynie utrzymać karę, zmniejszyć ją lub uchylićs. Wybór przez ukaranego drogi sądowej oznaczał złożenie w ciągu tygodnia zażalenia do sądu za pośrednictwem policji lub bezpośrednio. Przekazanie zażalenia za pośrednictwem policji miało na celu umożliwienie uchylenia przez nią kary i zakończenia tym samym postępowania. Jeżeli policja podtrzymywała swoje stanowisko, to przekazywała akta sprawy do sądu, który nie będąc związany wysokością wymiaru kary policyjnej, mógł nawet podwyższyć karę. Orzeczenie wydane przez komendanta wojewódzkiego lub przez sąd było prawomocne; w razie niezapłacenia grzywny ściągała ją w postępowaniu przymusowym bezpośrednio sama policja. W przypadku złośliwego uchylania się od wykonania kary policja miała prawo zamienić wymierzoną grzywnę na areszt zastępczy w wymiarze od jednego do sześciu tygodni. Kara była wykonywana w aresztach policyjnych'.

Występujący $\mathrm{w}$ praktyce orzecznictwa karno-administracyjnego podział drobnych czynów karalnych ze względu na rodzaj organu wymierzającego karę legł u podstaw dalszego wyodrębniania się grupy wykroczeń porządkowych. Pochodzące z 1953 r. zarządzenie w sprawie karania wykroczeń związanych $\mathrm{z}$ funkcjonowaniem gospodarki narodowej kwalifikowało lżejsze naruszenia prawa pozbawione charakteru kryminalnego jako wykroczenia porządkowe zagrożone karami wymierzanymi wyłącznie przez organy administracji. Gwałtowny wzrost liczby czynów karalnych zaliczanych do grupy wykroczeń porządkowych pociągał za sobą konieczność określenia jednolitych podstaw prawnych $\mathrm{w}$ zakresie kompetencji do wydania przepisów karno-administracyjnych, wysokości kar oraz trybu postępowania $\mathrm{w}$ związku z wymierzaniem kary administracyjnej. Dokonano tego w pochodzącym z 1955 r. rozporządzeniu, podkreślając dla celów propagandowych znaczenie zwalczania wykroczeń porządkowych jako instrumentu wychowania obywateli w duchu przestrzegania dyscypliny społecznej i rozwoju socjalistycznej świadomości. Rozporządzenie z 1955 r. określało pre-

\footnotetext{
8 Ibidem, s. 60.

9 Kommentar zum Ordungswidrigkeitsrecht der DDR, Band I, Berlin 1969, s. 14.
} 
cyzyjnie kompetencje organów administracji w zakresie wydawania przepisów karno-administracyjnych; wprowadzono w nim wymóg ustawowego określenia znamion czynów zaliczanych do grupy wykroczeń porządkowych. Jednocześnie zarządzenie to uchylało moc obowiązującą wszystkich aktów prawnych $\mathrm{z}$ tej dziedziny nieposiadających wyraźnego umocowania ustawowego. Ustalono granice kary grzywny orzekanej przez organa administracji, wprowadzając wymóg dostosowania do tych rozwiązań wszystkich aktów prawnych regulujących problematykę wykroczeń porządkowych ${ }^{10}$.

Wydanie rozporządzenia z 1955 r. pociągnęło za sobą próby określenia przez doktrynę kryterium odrębności wykroczeń porządkowych w postaci różnicy między bezprawiem kryminalnym a naruszeniem przepisów związanych z działalnością administracji państwowej. Karę administracyjną miało cechować z jednej strony wychowawcze oddziaływanie na ukaranego w kierunku przestrzegania prawa i dyscypliny społecznej, a z drugiej rezygnacja z represji karno-sądowej podyktowana niewielkim ciężarem gatunkowym czynu. W przeciwieństwie do wykroczeń porządkowych tradycyjne wykroczenia $\mathrm{z}$ racji ich rozpatrywania przez sąd na wniosek ukaranego traktowano w dalszym ciągu jako część prawa karnego ${ }^{11}$. Zreformowano natomiast system środków karnych stosowanych wobec sprawców tychże wykroczeń, ograniczając jego represyjność na rzecz oddziaływania wychowawczego. Pod koniec lat pięćdziesiątych zrezygnowano $\mathrm{z}$ wymierzania przez policję kary aresztu we wszystkich sprawach o wykroczenia oraz wprowadzono możliwość orzekania obok grzywny kar dodatkowych. Nowym środkiem o charakterze wychowawczym było stosowane zamiast kary pieniężnej ostrzeżenie, które nie wiązało się z uszczerbkiem majątkowym dla ukaranego. Działaniom tym towarzyszyło ograniczenie praktyki ustawodawstwa blankietowego na rzecz precyzyjnego określania przez ustawodawcę znamion wykroczenia i przewidzianych za nie kar oraz stopniowe przerzucanie do obszaru wykroczeń porządkowych czynów stanowiących wykroczenia w tradycyjnym tego słowa znaczeniu ${ }^{12}$.

Pierwsza połowa lat sześćdziesiątych przynosi definitywne wyodrębnienie wykroczeń porządkowych z prawa karnego połączone z ukształtowaniem podstawowych zasad postępowania i orzekania środków karnych w duchu socjalistycznym. Wydane w listopadzie 1963 r. rozporządzenie o zwalczaniu wykroczeń porządkowych sankcjonowało stworzone przez doktrynę kryteria materialnoprawne, decydujące o przynależności czynu karalnego do tej grupy, podkreślając zarazem potrzebę działalności profilaktycznej w kierunku zapobiegania naruszeniom przepisów związanych $\mathrm{z}$ wykonywaniem zadań państwowych przez

\footnotetext{
${ }^{10}$ W. Surkau, Verhütung und Bekämpfung von Ordnungswidrigkeiten, Berlin 1978, s. 14-15.

${ }^{11}$ Kommentar zum Ordnungswidrigkeitsrecht der DDR..., s. 15.

${ }^{12}$ W. Surkau, Verhütung..., s. 15.
} 
aparat administracji ${ }^{13}$. Z racji podobieństwa środków karnych orzekanych za wykroczenia porządkowe do kar dyscyplinarnych, uregulowano wzajemne relacje tych form reagowania na przypadki naruszenia przez obywateli dyscypliny społecznej, przyznając pierwszeństwo środkom dyscyplinarnym stosowanym przez kierownictwo zakładu pracy ${ }^{14}$.

Wydane w 1963 r. rozporządzenie stanowiło krok na drodze do kompleksowej regulacji prawa wykroczeń porządkowych, przygotowywanej od początku lat sześćdziesiątych równolegle z pracami kodyfikacyjnymi prawa i postępowania karnego $\mathrm{NRD}^{15}$. Wzajemna koordynacja tych prac miała na celu stworzenie jednolitego prawa wykroczeń porządkowych, które miało obejmować wszystkie czyny karalne niezaliczane na bazie kryterium szkodliwości społecznej czynu do grupy przestępstw. Oznaczało to zamiar likwidacji wykroczeń jako samodzielnej grupy czynów karalnych regulowanych przepisami kodeksu karnego oraz ustaw pozakodeksowych przez sprowadzenie ich do rangi wykroczeń porządkowych. Wybór takiego kierunku prac kodyfikacyjnych uzasadniano za pomocą argumentu, że występujący podział drobnych czynów karalnych na dwie grupy nie znajduje rzeczowego i prawnego uzasadnienia. Likwidacja tego podziału miała nastąpić w wyniku stworzenia kompleksowej kodyfikacji prawa wykroczeń porządkowych, której miało towarzyszyć precyzyjne określenie kryteriów decydujących o zakwalifikowaniu określonego czynu zabronionego do tej grupy ${ }^{16}$.

Pracom kodyfikacyjnym towarzyszyły dyskusje przedstawicieli doktryny na temat istoty i funkcji prawa wykroczeń porządkowych w systemie socjalistycznego prawa wschodnioniemieckiego. Pokłosiem tych dyskusji było zakwalifikowanie prawa wykroczeń porządkowych do prawa administracyjnego. $\mathrm{Z}$ racji pełnienia służebnej roli wobec zadań wykonywanych przez administrację państwową prawo wykroczeń porządkowych miało zapewnić prawidłowy przebieg procesów społeczno-gospodarczych w duchu socjalistycznym oraz wpływać na obywateli w kierunku dobrowolnego i świadomego przestrzegania prawa ${ }^{17}$. Specyfika prawa wykroczeń porządkowych miała polegać na kształtowaniu i wspieraniu dalszego rozwoju socjalistycznych stosunków społecznych, w ramach których czyny naruszające zasady współżycia społecznego lub utrudniające wykonywanie zadań państwowych miały być szybko i bez szkody dla interesów państwa oraz obywateli zwalczane. Represja stosowana wobec sprawcy

${ }^{13}$ H. Schmidt, Die Bekämpfung von Ordnungswidrigkeiten, „Neue Justiz” 1967, nr 10, s. 311.

${ }^{14}$ R. Schüsseler, Inhalt und Bedeutung der Verordnung zur Bekämpfung von Ordnungswidrigkeiten, „Neue Justiz” 1967, nr 2, s. 226.

${ }^{15}$ Komisja do spraw reformy prawa karnego NRD została utworzona w 1963 r. i składała się z 18 członków. Przewodniczącą komisji była dr Hilde Benjamin. W. Rosenthal, Strafreform des SED, Bonn und Berlin 1969, s. 5.

${ }^{16}$ Einige Grundzüge des künftigen Ordnungsstrafrechts, „Der Schöffe” 1967, nr 6, s. 196-197.

${ }^{17}$ Bekämpfung von Ordnungswidrigkeiten, „Der Schöffe” 1970, nr 1, s. 11. 
wykroczenia porządkowego popełnionego w sposób świadomy miała postać dolegliwości ekonomicznej zawartej w karze grzywny, natomiast w przypadku nieświadomego naruszenia przepisów porządkowych zalecano stosowanie środków wychowawczych. Karanie miało łączyć się z działalnością profilaktyczną prowadzoną przez organy administracji państwowej i gospodarczej, kierownictwo zakładów pracy, a także organizacje społeczne. Wysiłki tych instytucji w dziedzinie zwalczania i profilaktyki wykroczeń porządkowych służyły wspieraniu realizacji zadań państwa w dziedzinie politycznej, ekonomicznej i kulturalnej, miały także zapobiegać rozwojowi przestępczości o charakterze kryminalnym ${ }^{18}$.

2. Kodyfikacja prawa wykroczeń porządkowych została przeprowadzona $\mathrm{w}$ ramach socjalistycznej reformy prawa karnego materialnego i formalnego, która miała miejsce w styczniu 1968 r. ${ }^{19}$ Izba Ludowa NRD uchwaliła wówczas ustawy stanowiące trzon ustawodawstwa karnego: kodeks karny, kodeks postępowania karnego oraz ustawy o wykonywaniu kar pozbawienia wolności i włączaniu zwolnionych więźniów do życia społecznego. Kompleksowa regulacja prawa karnego NRD obejmowała ponadto ustawę o zwalczaniu wykroczeń porządkowych (dalej skrót OWG) ${ }^{20}$, która weszła w życie 1 lipca 1968 r. ${ }^{21}$ Nowe ustawodawstwo karne istotnie zmieniało dotychczasowy system niemieckiego prawa karnego, sięgający swoimi korzeniami XIX stulecia. Sztandarowy akt prawny kodyfikacji - kodeks karny $\mathrm{NRD}^{22}$ zaliczał do przestępstw tylko zbrodnie i występki, natomiast czynom zabronionym „naruszającym prawnie chronione interesy społeczne lub obywateli o nieznacznych skutkach czynu i o niewielkiej winie sprawcy" odmawiał charakteru przestępstwa ${ }^{23}$. Tego rodzaju czyny karalne były traktowane jako wykroczenia, w ramach których występował podział na tzw. przewinienia oraz wykroczenia porządkowe ${ }^{24}$.

Obydwie te grupy czynów zabronionych cechował niewielki stopień społecznego niebezpieczeństwa oraz zagrożenie karą zasadniczą grzywny w niezbyt wysokim wymiarze. Sprawcy tych czynów nie podlegali w zasadzie jurysdyk-

${ }^{18}$ W. Surkau, Verhütung..., s. 19-20.

${ }^{19}$ Projekty aktów prawnych składających się na kodyfikację prawa karnego NRD zostały opracowane na początku 1967 r. Izba Ludowa uchwaliła je w pierwszym czytaniu 15 grudnia 1967 r. Następnie projekty skierowano do komisji sejmowych, które dokonały całościowej oceny i wniosły do nich poprawki. Drugie czytanie projektów aktów prawnych tworzących kodyfikację prawa karnego NRD miało miejsce 12 stycznia 1968 r., ustawy zostały przyjęte przez Izbę Ludową jednomyślnie. W. Rosenthal, Strafreform..., s. 5.

${ }^{20}$ Skrót OWG był powszechnie stosowany w NRD i pochodzi od niemieckiej nazwy tego aktu prawnego - Gesetz zur Bekämpfung von Ordnungswidrigkeiten.

${ }^{21}$ H. Benjamin, M. Becker, K. Görtner, W. Schriewer, Zur Herausblidung des sozialistischen Strafrechts in der Deutschen Demokratischen Republik, ,Staat und Recht” 1969, Heft 12, s. 1852.

22 Ustawa z dnia 12 stycznia 1968 r. Kodeks karny (GBl I, 1975, nr 3).

${ }^{23}$ Stanowił o tym $\$ 1$ Kodeksu karnego NRD z dnia 12 stycznia $1968 \mathrm{r}$.

${ }^{24}$ F. Müller, R. Bunsch, Zur Regelung der Verfehlungen, „Neue Justiz” 1967, nr 10, s. 308. 
cji sądów powszechnych, lecz organów administracji państwowej lub społecznych organów wymiaru sprawiedliwości. Między przewinieniem a wykroczeniem porządkowym występowały jednak odmienności, które ustawodawca NRD uznał za na tyle istotne, że oddzielnie uregulował te dwie grupy czynów karalnych. Przewinienia naruszały zasady współżycia społecznego w stosunkach między obywatelami lub też prowadziły do konfliktu między sprawcą a poszkodowanym w przypadku naruszenia dobra o charakterze materialnym. Wykroczenia porządkowe natomiast $\mathrm{w}$ mniejszym stopniu szkodziły relacjom między konkretnymi osobami, gdyż z reguły polegały na nieprzestrzeganiu przepisów związanych z wykonywaniem przez aparat administracji zadań państwowych, czyli naruszały dobro o charakterze ogólnym w postaci porządku i dyscypliny społecznej ${ }^{25}$.

Stanowiące nową grupę czynów karalnych przewinienia powstały wskutek dekryminalizacji tych dotychczasowych występków, które w praktyce stanowiły najczęściej popełniane czyny karalne o małej szkodliwości społecznej lub które były ścigane z oskarżenia prywatnego. Do pierwszej grupy należały występki przeciwko własności społecznej lub prywatnej, w przypadku których wartość wyrządzonej czynem szkody nie przekraczała 50 marek. Masowe występowanie tego rodzaju czynów, stanowiących blisko $20 \%$ wszystkich przestępstw notowanych w statystykach przestępczości NRD, rodziło problem niejednolitej polityki ścigania występków przeciwko własności w zależności od rozmiaru wyrządzonej szkody. O ile przestępstwa i występki przeciwko własności o znacznym stopniu szkodliwości społecznej czynu były w zasadzie ścigane w trybie postępowania karnego, to w odniesieniu do pozostałych występków z tej grupy rezygnowano $\mathrm{z}$ prowadzenia procesu karnego na rzecz umorzenia postępowania lub przekazania sprawy społecznym organom pozasądowym celem zastosowania środków o charakterze wychowawczym. Podobne problemy praktyczne występowały w przypadku występków ściganych wcześniej na podstawie oskarżenia prywatnego, takich jak zniewaga, pomówienie i naruszenie spokoju domowego. Wobec likwidacji trybu oskarżenia prywatnego czyny te zostały w 1963 r. objęte ściganiem z urzędu, chociaż w przekonaniu społecznym nie miały charakteru przestępstw. Zgodnie z zasadą legalizmu wobec sprawców tego rodzaju występków powinno być prowadzone postępowanie sądowe oraz stosowane środki karne przewidziane w kodeksie karnym, jednak nie były one adekwatne do stopnia szkodliwości społecznej tych czynów. Problem ten próbowano rozwiązać na gruncie zasady oportunizmu, rezygnując $\mathrm{z}$ wszczynania postępowania karnego wobec sprawców występków ocenianych przez organy ścigania jako czyny o znikomym ładunku szkodliwości materialnej. Taka postawa nie budziła więk-

${ }^{25}$ J. Skupiński, Prawo o wykroczeniach w europejskich państwach socjalistycznych, t. 2, Niemiecka Republika Demokratyczna, Warszawa 1977, s. 8. 
szych zastrzeżeń $\mathrm{w}$ przypadku występków ściganych wcześniej z oskarżenia prywatnego, natomiast władze państwowe negatywnie oceniały bezczynność organów państwa w dziedzinie występków przeciwko własności społecznej. Własność ta stanowiła podstawę ustroju społeczno-gospodarczego NRD, stąd nawet drobne jej naruszenia traktowano w statystykach przestępczości jako czyny o charakterze kryminalnym, które powinny spotykać się z szybką i skuteczną reakcją organów państwa. Narastający problem braku odpowiednich środków zwalczania drobnych występków rozwiązano przez wyłączenie ich z kategorii przestępstw, co zostało wyraźnie podkreślone w przepisach kodeksu karnego NRD oraz intytulacji jego poszczególnych rozdziałów. Kodeks karny NRD stanowił jedyny akt prawny poświęcony problematyce przewinieńn ${ }^{26}$, wobec których stosowano zasady odpowiedzialności określone w części ogólnej tego kodeksu. W odniesieniu do sprawców przewinień nie miały jednak zastosowania przewidziane tym kodeksem kary, gdyż stanowił on że „środki odpowiedzialności za wykroczenia podlegają odrębnej regulacji prawnej"27. Przepisy części szczególnej kodeksu karnego tworzące poszczególne stany faktyczne przewinień stanowiły o odpowiedzialności przed społecznymi organami wymiaru sprawiedliwości lub jeszcze bardziej lakonicznie o samej odpowiedzialności za przewinienie ${ }^{28}$.

Kodeks karny NRD przewidywał cztery stany faktyczne, które w przypadku znikomej szkodliwości społecznej czynu mogły być traktowane jako przewinienia. Były to zaliczane wcześniej do grupy występków czyny zabronione naruszenia miru domowego, obrazy, zniesławienia oraz kradzieży lub oszustwa. Przewinienia kradzieży lub oszustwa stanowiły postać uprzywilejowaną w stosunku do stanowiących występki typów podstawowych ${ }^{29}$. Granica wysokości szkody wyrządzonej czynem zabronionym, poniżej której kradzież lub oszustwo traktowano jako przewinienie, wynosiła 50 marek. W praktyce odchodzono od ścisłego stosowania tej przesłanki, kwalifikując jako przewinienia czyny, których skutkiem była szkoda w mieniu „nie przekraczająca znacząco kwoty 50 marek” ${ }^{0}$. Brano również pod uwagę okoliczności podmiotowe czynu, takie jak znikoma wina sprawcy, jego osobowość, czy dopuszczenie się kradzieży lub oszustwa po raz pierwszy. Recydywa oznaczała automatyczne kwalifikowanie czynu zabronionego jako występku, bez znaczenia była tutaj wysokość szkody wyrządzonej

${ }^{26}$ Pomimo zawartego w kodeksie karnym upoważnienia do uregulowania problematyki przewinień, w innych aktach rangi ustawowej nie zdecydowano się na skorzystanie z tej możliwości. B. Schubel, Geschichte und Gegenwart außerrechtlicher Erledigung von Strafsachen durch ehrenamtliche Schiedsinstanzen in den neuen Bundesländern, Berlin 1997, s. 63-65.

${ }^{27} \$ 4$ Kodeksu karnego NRD z dnia 12 stycznia 1968 r.

${ }^{28}$ F. Herzog, Rechtspflege - Sache des Ganzes Volkes?, Baden-Baden 1999, s. 10-11.

${ }^{29}$ Typami podstawowymi były: kradzież mienia społecznego, oszustwo na szkodę mienia społecznego, kradzież mienia osobistego lub prywatnego, oszustwo na szkodę mienia osobistego lub prywatnego. J. Skupiński, Prawo o wykroczeniach..., s. 13-14.

${ }^{30}$ B. Schubel, Geschichte und Gegenwart..., s. 66. 
przez sprawcę. Odmiennie dokonano typizacji czynów karalnych polegających na obrazie i zniesławieniu oraz naruszeniu miru domowego, w przypadku których przewinienie stanowiło typ podstawowy, a typem kwalifikowanym był występek. Przewinienie naruszenia miru domowego posiadało także postać uprzywilejowaną, było nią wykroczenie porządkowe. Wprawdzie liczba przewinień regulowanych kodeksem karnym była niewielka, lecz te cztery przypadki dotyczyły czynów często popełnianych w praktyce i stanowiących łącznie poważną pozycję w statystyce przestępczości ${ }^{31}$.

Przekwalifikowanie dotychczasowych występków w przewinienia nieposiadające charakteru przestępstwa pociągało za sobą nieuwzględnianie tej grupy czynów karalnych w statystykach kryminalnych. Dlatego też po wejściu w życie w 1968 r. nowego kodeksu karnego odnotowano spadek przestępczości kryminalnej w NRD, odczuwalny zwłaszcza $\mathrm{w}$ dziedzinie przestępstw przeciwko własności. W drugiej połowie lat sześćdziesiątych stanowiły one ponad połowę czynów objętych statystykami, przykładowo w 1966 r. 54\% wykrytych przestępstw było wymierzonych przeciwko własności. Czyny o niewielkim stopniu szkodliwości społecznej, wyrządzające drobne szkody w mieniu, stanowiły aż $80 \%$ przestępstw. Odebranie tym czynom charakteru przestępstwa skutkowało pomijaniem ich w statystykach, które w 1968 r. wykazywały znaczący spadek zagrożenia przestępczością kryminalną. Zostało to wykorzystane przez rządzącą SED do celów propagandowych jako wyraz postępu na drodze do stworzenia społeczeństwa socjalistycznego. Według partyjnych propagandystów ideologia marksistowsko-leninowska zakładała stopniowe zanikanie przestępczości kryminalnej wraz z utrwalaniem socjalistycznych zasad współżycia społecznego ${ }^{32}$.

Regulowane kodeksem karnym przewinienia dzieliły się na dwie grupy według kryterium podległości sprawy jurysdykcji określonego organu orzekającego. Do kompetencji sądów społecznych - komisji konfliktowych działających w zakładach pracy oraz komisji rozjemczych - przekazano orzekanie w sprawach o obrazę, zniesławienia oraz naruszenie miru domowego. Rozpatrzenie sprawy przez sąd społeczny następowało na wniosek pokrzywdzonego, kolektywu pracowniczego, mieszkańców domu lub wskutek przekazania sprawy temu sądowi przez policję ludową albo organy dyscyplinarne ${ }^{33}$. Wprowadzenie na szeroką skalę orzecznictwa sądów społecznych do procesu rozpoznawania spraw o czyny zabronione stanowiło jedną z ważniejszych cech kodyfikacji prawa karnego NRD, które w sprawach o drobniejsze czyny karalne przewidywało stosowanie rozmaitych form oddziaływania społeczno-wychowawczego. Orzecz-

\footnotetext{
${ }^{31}$ Die Bekämpfung von Verfehlungen durch die Deutsche Volkspolizei, Berlin 1977, s. 63-64.

${ }^{32}$ H. Hildebrand, Straftaten und Verfehlungen im neuen Strafrecht der DDR, ,Jahrbuch für Ostrecht”, 1 Halbjahresheft, September 1968, s. 15.

${ }_{33}$ E. Korting, Grundtendenzen in der Entwicklung der gesellschaftlichen Gerichte der DDR, „Jahrbuch für Ostrecht" 1981, t. XXII, s. 111-112.
} 
nictwo sądów społecznych obejmowało również wykroczenia porządkowe, a nawet występki ${ }^{34}$ przekazywane pod określonymi warunkami przez prokuratora lub sąd powszechny ${ }^{35}$. Sprawy o przewinienia stanowiły ważny aspekt działalności orzeczniczej komisji rozjemczych; w latach siedemdziesiątych ich udział procentowy w całokształcie rozpoznawanych spraw sięgał prawie pięćdziesięciu procent ${ }^{36}$. Znacznie mniejszy, bo zaledwie kilkunastoprocentowy, był udział tej grupy spraw w orzecznictwie komisji konfliktowych ${ }^{37}$, gdyż z racji funkcjonowania w uspołecznionych zakładach pracy komisje te skupiały się na sporach z zakresu prawa pracy. Sądy społeczne mogły stosować środki wychowawcze polegające na zobowiązaniu sprawcy czynu zabronionego do usprawiedliwienia się przed pokrzywdzonym lub kolektywem, naprawienia szkody drogą naturalnej restytucji lub zapłaty odszkodowania oraz publicznego odwołania obrazy albo zniesławienia. Innym środkiem oddziaływania wychowawczego była udzielana ukaranemu przez sąd nagana, z kolei charakter represji majątkowej miała orzekana w szczególnym trybie kara grzywny ${ }^{38}$. Przy rozpoznawaniu spraw o obrazę, zniesławienie i naruszenie miru domowego sąd społeczny dążył do pojednania obwinionego obywatela $\mathrm{z}$ wnioskodawcą, a w razie dojścia do pojednania nie stosowano środków wychowawczych.

${ }^{34}$ Do kompetencji sądów społecznych przekazano znaczną część występków składających się na poszczególne rodzaje przestępstw; przykładowo w $1969 \mathrm{r}$. miało to miejsce w stosunku do $49 \%$ spraw o kradzieże i oszustwa na szkodę własności społecznej, 46,8\% spraw o kradzieże i oszustwa na szkodę osób prywatnych, $33,5 \%$ spraw o naruszenie bezpieczeństwa ruchu drogowego, $54,2 \%$ spraw o umyślne uszkodzenie ciała, $61,6 \%$ spraw o spowodowanie pożaru wskutek niedbalstwa, $25,9 \%$ spraw o naruszenie przepisów bhp. M. Rybicki, Sądy społeczne w europejskich państwach socjalistycznych, Warszawa 1974, s. 121.

${ }^{35}$ Przekazanie przez prokuratora lub sąd powszechny sprawy o występek do sądu społecznego zależało od spełnienia następujących warunków: sprawa została całkowicie wyjaśniona, a sprawca przyznał się do winy; z uwagi na zaistniałe skutki oraz winę nie można uznać sprawcy czynu za „aspołecznego w znacznym stopniu"; zdaniem organu przekazującego, wychowawcze oddziaływanie sądu będzie skuteczne. W. Hanstsche, R. Winkler, K. Gorner, Neue Bestimmungen uber die Tatigkeit der Konflikt - und Schiedskommissionen - weitere Ausgestaltung der sozialistischen Rechtsordnug, „Neue Justiz” 1968, nr 24, s. 741.

${ }^{36}$ W 1969 r. na ogólną liczbę rozpoznanych przez komisje rozjemcze 29701 spraw 14498 dotyczyło przewinień; w 1971 liczby te wynosiły odpowiednio: 28708 i 13549, a w 1976 r. 23371 i 10116. Tendencję spadkową w latach osiemdziesiątych najlepiej obrazują dane z 1983 r., kiedy to na 19834 rozpoznanych spraw zaledwie 7070 dotyczyło wykroczeń porządkowych. B. Schubel, Geschichte und Gegenwart..., s. 316-317.

${ }^{37}$ Przykładowo w 1969 r. komisje konfliktowe rozpatrzyły 3231 spraw o przewinienia na tle ogólnej liczby 33854 rozpoznanych spraw. W roku 1975 liczby te wynosiły odpowiednio 4197 i 55289 , a w 1980: 3862 i 58 460. Rekordowy pod względem liczby rozpatrzonych spraw - 73303 - był rok 1985, lecz w sprawach o przewinienia zapadły jedynie 3604 orzeczenia. B. Schubel, Geschichte und Gegenwart..., s. 318-319.

${ }^{38}$ Grzywna miała postać zobowiązania obywatela przez sąd społeczny do zapłacenia kary pieniężnej od 5 do 50 marek w przypadku czynów zaliczanych do obydwu grup wykroczeń, a przy występkach przeciw własności do trzykrotnej wartości spowodowanej szkody, najwyżej jednak 150 marek. H. T. Schmidt, Wesen und Entwicklung der Konflikt- und Schiedskommissionen in der DDR (1952-1969), „Jahrbuch fur Ostrecht”, Band X, 2 Halbjahresheft, 1969, s. 81. 
Orzeczenia sądów społecznych były wykonywane drogą zastosowania przymusu państwowego, co $\mathrm{w}$ praktyce miało miejsce $\mathrm{w}$ przypadku posiadających charakter materialny kar grzywny i zobowiązań do naprawienia szkody. Sądy społeczne orzekały jako organy pierwszej instancji, od ich orzeczeń przysługiwało wnioskodawcy i ukaranemu prawo odwołania do sądu powszechnego pierwszej instancji - sądu powiatowego ${ }^{39}$.

Najczęściej występujące w praktyce przewinienia polegające na drobnej kradzieży i drobnym oszustwie zostały przekazane orzecznictwu Policji Ludowej, co uzasadniano potrzebą szybkiej reakcji ze strony organu państwowego. Policja Ludowa mogła wymierzyć sprawcy przewinienia karę grzywny w wysokości do 300 marek w trybie tzw. policyjnego zarządzenia karnego. Było ono wydawane na podstawie notatek służbowych bez przeprowadzenia rozprawy i udziału stron, jednak zawierało wszystkie istotne dla orzeczenia w sprawie karnej elementy oraz uzasadnienie. Był to jedyny środek karny orzekany $w$ tym trybie, gdyż w przeciwieństwie do sądów społecznych policja nie stosowała środków oddziaływania społeczno-wychowawczego. Jeżeli organ policji doszedł do przekonania o potrzebie zastosowania takiego środka, to mógł przekazać sprawę do sądu społecznego lub nawet wnioskować o pociągnięcie sprawcy do odpowiedzialności dyscyplinarnej przez kierownictwo zakładu pracy ${ }^{40}$. W sprawach przewinień przeciwko własności, popełnionych przez klientów $\mathrm{w}$ „socjalistycznym handlu detalicznym", placówki handlu detalicznego mogły nakładać kary grzywny w trybie mandatowym do wysokości trzykrotnej wartości wyrządzonej szkody. Mandat powinien zostać uiszczony na miejscu lub w terminie nieprzekraczającym 6 dni. Jeżeli sprawca odmawiał zapłaty lub nie chciał okazać dowodu osobistego, to sprawa była przekazywana policji i rozstrzygana w trybie zarządzenia karnego ${ }^{41}$.

Policyjne zarządzenie karne wymierzające grzywnę nie miało charakteru ostatecznego, gdyż nawiązując do tradycji niemieckiego modelu orzecznictwa w sprawach o wykroczenia, przyznano ukaranemu i wnioskodawcy prawo złożenia wniosku o rozpoznanie sprawy przez sąd. Wniosek był składany za pośrednictwem organów policji, które mogły cofnąć wydane zarządzenie karne lub też utrzymując je, przekazać akta sprawy sądowi powiatowemu. Sąd miał obowiązek rozpoznania sprawy od początku i wydania ostatecznego orzeczenia, w którym zatwierdzał nałożoną przez policję grzywnę, obniżał ją lub uniewinniał sprawcę. Wynika $\mathrm{z}$ tego, że sąd był związany zakazem reformationis in peius i nie mógł orzec wyższej kary pieniężnej².

${ }^{39}$ J. Skupiński, Prawo o wykroczeniach..., s. 24-25.

${ }^{40}$ Die Bekämpfung von Verfehlungen...., s. 101-105.

${ }_{41}$ J. Skupiński, Prawo o wykroczeniach..., s. 39.

${ }^{42}$ H. Luers, Das Polizeirecht in der DDR. Aufgaben, Befugniss und Organisation der Deutschen Volkspolizei, Köln1974, s. 66-67. 
3. Drugą grupę czynów karalnych niezaliczanych do przestępstw stanowiły wykroczenia porządkowe. Miały one postać drobnych naruszeń porządku społecznego i dyscypliny związanych $\mathrm{z}$ wykonywaniem przez państwo jego zadań. Po reformie 1968 r. zaliczano do nich także dotychczasowe wykroczenia regulowane kodeksem karnym Rzeszy Niemieckiej ${ }^{43}$, których przekształcenie w wykroczenia porządkowe pozbawiało ukaranego prawa żądania rozpatrzenia sprawy przez sąd. Ponadto jako wykroczenia porządkowe mogły być potraktowane czyny karalne wypełniające wprawdzie przedmiotowe znamiona występku, lecz cechujące się nieznacznym stopniem winy sprawcy lub skutków jego czynu. Wprowadzenie takiego kryterium wartościującego jako przesłanki zmiany charakteru czynu z przestępstwa w wykroczenie porządkowe dawało organom ścigania swobodę decyzji co do wszczęcia postępowania karnego lub też przekazania sprawy na drogę karno-administracyjną. Wybór drugiej możliwości oznaczał pozbawienie prawa do rozpatrzenia sprawy przez niezawisły sąd osób, których sprzeczne z prawem działanie wypełniało znamiona chuligaństwa, spekulacji, nielegalnego zgromadzenia oraz wielu innych występków ${ }^{44}$.

Problematykę wykroczeń porządkowych regulowała jedna $\mathrm{z}$ ustaw składających się na kompleksową reformę prawa karnego NRD - OWG. Zawierała ona przepisy z zakresu zasad odpowiedzialności, kar i innych środków prawnych, wykonywania orzeczeń oraz postępowania w sprawach o wykroczenia porządkowe. Ponadto zawierała odrębne regulacje poświęcone wykroczeniom celnym i dewizowym, które wprawdzie traktowano jako przynależne do grupy wykroczeń porządkowych, lecz ze względu na specyfikę tych czynów karalnych nie określono ich tym mianem. Cechą charakterystyczną OWG było syntetyczne, a przez to ramowe ujęcie przepisów materialnych dotyczących podstawowych zasad odpowiedzialności karno-administracyjnej, jak również przepisów formalnych. Ustawa nie regulowała poszczególnych typów wykroczeń porządkowych ani grożących za nie sankcji, zawierała natomiast upoważnienie do wydawania przepisów określających poszczególne stany faktyczne. OWG była zatem ustawą blankietową, ustalającą podstawowe zasady odpowiedzialności karno-administracyjnej ${ }^{45}$. Ustawa określała w jakich aktach normatywnych i przez jakie organy mogą być wydawane przepisy kreujące stany faktyczne wykroczeń

${ }^{43}$ B. Schubel, Geschichte und Gegenwart..., s. 90.

${ }^{44}$ Jako wykroczenia porządkowe mogły być zakwalifikowane czyny wypełniające znamiona takich występków, jak: naruszenie spokoju domowego, naruszenie przepisów podatkowych i o cenach, przygotowywanie fałszywych środków płatniczych, zagrożenie bezpieczeństwa przeciwpożarowego, uszkodzenie plakatów z publicznymi obwieszczeniami, przebywanie w miejscach niedozwolonych, utrudnianie akcji ratunkowej, zniszczenie przedmiotu znajdującego się w depozycie urzędowym. H. Hildebrand, Straftaten und Verfehlungen...., s. 17.

${ }_{45}$ Założeniem leżącym u podstaw wydania OWG było „ukierunkowanie aktów normatywnych, ustanawiających poszczególne rodzaje odpowiedzialności i uregulowanie podstawowych zasad odpowiedzialności, a także ustalenie zasadniczych form postępowania i orzecznictwa karno-administracyjnego". Kommentar zum Ordnungswidrigkeitsrecht...., s. 16-17. 
porządkowych i grożące za nie sankcje ${ }^{46}$. Wychowawczy charakter orzecznictwa karno-administracyjnego miało podkreślać subsydiarne upoważnienie organów państwowych do wydawania przepisów regulujących ściganie wykroczeń porządkowych naruszających dyscyplinę społeczną. Upoważnienie to mogło być wykorzystane w sytuacji, gdy dla zapewnienia tej dyscypliny nie wystarczały środki o charakterze wychowawczym lub dyscyplinarnym bądź przepisy o odpowiedzialności materialnej. Na podstawie zawartego w ustawie upoważnienia przepisy składające się na część szczególną prawa wykroczeń porządkowych NRD zostały uregulowane w pochodzącym z maja $1968 \mathrm{r}$. rozporządzeniu oraz w licznych aktach dodatkowych ${ }^{47}$.

Ustawa dawała wyraz odcięciu wykroczeń porządkowych od przestępstw, wskazując $\mathrm{w}$ pierwszym rzędzie dyrektywy walki z wykroczeniami porządkowymi. Orzecznictwo karno-administracyjne w sprawach o wykroczenia porządkowe miało spełniać przede wszystkim funkcje wychowawcze, przyczyniając się do „rozwijania u obywateli dobrowolnej i świadomej dyscypliny zmierzającej do zapewnienia zasad współżycia w socjalistycznym społeczeństwie”. Przestrzeganiu przez obywateli dyscypliny społecznej przypisywano funkcje prewencyjne w zakresie zapobiegania przestępczości kryminalnej, której występowanie godziło w podstawy socjalistycznej praworządności ${ }^{48}$. Wzorem radzieckim w NRD i innych krajach „demokracji ludowej” wiązano praworządność nie tylko z legalnością działania organów państwowych, lecz także z przestrzeganiem przepisów prawa przez obywateli.

Kluczowa dla samodzielnego bytu prawa wykroczeń porządkowych, zawarta w OWG definicja materialna, określała tego rodzaju czyn jako zawinione naruszenie prawa, wynikające z nieprzestrzegania dyscypliny społecznej. Skutkiem wykroczenia porządkowego było utrudnianie realizacji zadań państwowych przez aparat administracji lub złamanie zasad współżycia w społeczeństwie socjalistycznym. Dotyczyło to zwłaszcza takich dziedzin, jak: działalność organów państwowych, życie gospodarcze, bezpieczeństwo i porządek publiczny, środki nadzoru i kontroli. Przykładowy katalog dóbr chronionych przez OWG podkreślał prymat interesu państwowego, gdyż wyliczając sfery objęte penalizacją ustawodawca skupił się na wykonywaniu zadań państwowych w dziedzinie społeczno-gospodarczej. Czyn naruszający interes społeczny lub interesy po-

${ }^{46}$ Zgodnie $\mathrm{z} \$ 3$ OWG przepisy karno-porządkowe mogły być ustanawiane w ustawach Izby Ludowej, dekretach Rady Państwa, zarządzeniach Narodowej Rady Obrony, w rozporządzeniach i uchwałach Rady Ministrów. W ramach przekazanych przez Radę Ministrów kompetencji przepisy karno-porządkowe mogli wydawać poszczególni ministrowie oraz kierownicy centralnych organów administracji. $\mathrm{W} \$ 4$ ustawa przewidywała możliwość przekazania terenowym przedstawicielstwom ludowym kompetencji do stanowienia uchwał określających obowiązki prawne, za których naruszenie mogły być stosowane środki karno-porządkowe.

${ }^{47}$ J. Śliwowski, B. Koch, Ustawa Niemieckiej Republiki Demokratycznej o zwalczaniu wykroczeń,„Zagadnienia Karno-Administracyjne" 1968, nr 4, s. 86-87.

${ }^{48}$ H. Luers, Das Polizeirecht..., s. 67-68. 
szczególnych obywateli był kwalifikowany jako wykroczenia porządkowe, jeżeli cechował go nieznaczny stopień szkodliwości społecznej. Zasady odpowiedzialności za wykroczenia porządkowe zostały określone w sposób ogólny, gdyż twórcy ustawy wyszli z założenia, że będzie ona stosowana w praktyce przez osoby i organy nie zawsze posiadające odpowiednie kwalifikacje prawnicze ${ }^{49}$.

Zdecydowanie obszerniej potraktowano $\mathrm{w}$ ustawie problem stosowania sankcji karno-administracyjnych, podkreślając zwłaszcza aspekt prewencji ogólnej. Kara administracyjna miała nie tylko wdrożyć naruszającego prawo do zdyscyplinowanego wykonywania ciążących na nim zadań, lecz również wywrzeć wpływ na sprawcę oraz innych obywateli w kierunku profilaktyki zapobiegania dalszym naruszeniom prawa. Wychowawczy charakter reakcji na popełnienie wykroczenia porządkowego miała wzmacniać pozostawiona swobodnemu uznaniu organu orzekającego możliwość odstąpienia od wymierzania kary i poprzestania na ustnym lub pisemnym pouczeniu sprawcy, jeżeli czyn stanowił konsekwencję przypadkowej nieuwagi ${ }^{50}$. Z kolei ustawa nakazywała wymierzenie kary administracyjnej w sytuacji, gdy wykroczenie porządkowe zostało popełnione wskutek szczególnie niezdyscyplinowanego nastawienia sprawcy, a waga i rodzaj dokonanego naruszenia przemawiały za potrzebą silniejszego oddziaływania wychowawczego. Przewidziane przez ustawę kary administracyjne to nagana oraz grzywna w wysokości do 300 marek $^{51}$. Łagodniejszą odmianą kary grzywny było stosowane w trybie postępowania mandatowego upomnienie z wpłatą porządkową do 10 marek. W wyjątkowych sytuacjach, gdy zdaniem organu orzekającego zachodziła potrzeba surowego ukarania sprawcy ze względu na jego osobowość i okoliczności popełnienia czynu ${ }^{52}$, ustawa dopuszczała wymierzenie grzywny w wysokości do 1000 marek. Katalog kar

${ }^{49}$ Oprócz zamieszczenia definicji materialnej wykroczenia porządkowego, OWG regulowała także w sposób ogólny problematykę umyślności i nieumyślności oraz sytuację zawinionego upojenia alkoholowego. Nie zamieszczono natomiast w ustawie okoliczności wyłączających odpowiedzialność, pozostawiając praktyce możliwość uwzględnienia tych kwestii na gruncie materialnej definicji wykroczenia porządkowego oraz zasady celowości ścigania i karania tych wykroczeń. H. Liening, H. Schmidt, R. Winkler, Zu einigen Fragen des Ordnungswidrigkeitsrechts aus der Sicht der Rechtspflegeorgane, „Neue Justiz” 1969 , nr 23, s. 732-733.

${ }^{50}$ H. Schmidt, R. Winkler, Zur Beratung und Entscheidung von Ordnungswidrigkeiten durch Schiedsund Konfliktkommissionen, „Der Schöffe” 1968, nr 5, s. 154-155.

${ }^{51}$ Po nowelizacji OWG dokonanej w 1974 r. grzywna mogła wynieść 500 marek w przypadku wykroczeń przeciwko porządkowi i bezpieczeństwu publicznemu. Kolejna nowelizacja z 1979 r. wprowadziła górne zagrożenie karą grzywny w wysokości 500 marek w odniesieniu do wszystkich rodzajów wykroczeń porządkowych. Ordnungswidrigkeitrecht der DDR. Kommentar zum Ordnungswidrigkeitsgesetz und zur Ordnungswidirgkeitsverordnung, Berlin 1989, s. 11.

${ }^{52} \S 5$ OWG przewidywał zagrożenie karą porządkową w wysokości do 1000 marek w przypadku popełnienia umyślnego wykroczenia celem osiągnięcia korzyści majątkowych lub z innych motywów wskazujących na lekceważenie przez sprawcę porządku publicznego. Górna granica kary grzywny mogła wynieść 1000 marek w przypadku recydywy, za którą uważano dwukrotne ukaranie karą porządkową w okresie dwóch lat. Grzywna w tym wymiarze mogła być orzekana za wykroczenie porządkowe powodujące znaczną szkodę majątkową. 
administracyjnych nie przewidywał środków represji osobistej w postaci aresztu zasadniczego ani kary aresztu zastępczego na wypadek nieuiszczenia orzeczonej grzywny, co miało podkreślać wychowawczy charakter ustawy. Obok kar administracyjnych OWG dopuszczała stosowanie tzw. dodatkowych środków karno-porządkowych w postaci pozbawienia lub ograniczenia zezwoleń udzielanych przez organy państwowe, przepadku przedmiotów lub ich równowartości, obowiązku naprawienia szkody. Typowo wychowawczy charakter miały takie środki dodatkowe, jak obowiązek wykonywania pracy społecznie użytecznej, publiczne ogłoszenie na koszt naruszającego prawo oraz stosowane samoistnie w przypadku odstąpienia od wymierzania kary zapisanie wzmianki o naruszeniu obowiązku prawnego lub wezwanie sprawcy celem pouczenia o treści takich obowiązków ${ }^{53}$.

4. Przepisy proceduralne ustawy dotyczące ścigania wykroczeń porządkowych cechowała typowa dla jej konstrukcji blankietowość. OWG stanowiła, że postępowanie w sprawach o wykroczenia porządkowe toczy się jednoosobowo przed organami administracji, nie wskazując przy tym konkretnych organów sprawujących orzecznictwo karno-administracyjne. Ustawodawca określił tylko jakim urzędnikom na poszczególnych szczeblach hierarchii administracyjnej można było udzielić uprawnień do orzekania, ramowo wskazał także właściwość resortową poszczególnych pionów administracyjnych. Prowadzić sprawę miały te organy, których zakres działania został wykroczeniem naruszony i które dysponowały największą wiedzą fachową $\mathrm{w}$ danym obszarze. W formie ogólnych zasad określono właściwość miejscową organów orzekających ${ }^{54}$.

Wszczęcie postępowania następowało $\mathrm{z}$ urzędu przez organ orzekający na podstawie inicjatywy innych organów państwowych i gospodarczych oraz wskutek zawiadomienia przez osoby prywatne lub organizacje społeczne. Wiążące były jedynie wnioski prokuratora oraz inspekcji robotniczo-chłopskiej, w pozostałych przypadkach możliwe było odstąpienie od wszczęcia postępowania na rzecz zastosowania odpowiedzialności dyscyplinarnej, odszkodowawczej lub innych środków wychowawczych. Samo postępowanie karno-administracyjne miało w zasadzie charakter inkwizycyjny, gdyż toczyło się przed jednoosobowymi organami administracji, bez udziału oskarżyciela i obwinionego, który nie mógł korzystać z pomocy obrońcy. Obwinionemu przysługiwało prawo składania wyjaśnień i ustosunkowania się do zgromadzonych dowodów, występował on zatem $\mathrm{w}$ charakterze strony postępowania administracyjnego ${ }^{55}$. Wyłomem na rzecz kontradyktoryjności postępowania była możliwość przeprowadzenia

${ }^{53}$ Ordnungswidrigkeitsrecht der DDR..., s. 32-35.

${ }^{54}$ J. Śliwowski, B. Koch, Ustawa Niemieckiej Republiki Demokratycznej..., s. 90-91.

${ }^{55}$ N. Debski, Das polnische Übertretungsrecht im Vergleich mit dem Ordnungswidrigkeitsrecht der DDR, „Neue Justiz” 1986, nr 3, s. 107. 
rozprawy, jeżeli zdaniem organu orzekającego zachodziła taka potrzeba. Było to wskazane zwłaszcza w przypadku spraw większej wagi, rozpoznawanych przez lokalne organy zarządzająco-wykonawcze - rady terenowe ${ }^{56}$. Wychowawcze znaczenie rozprawy wzmacniało zawarte w ustawie zalecenie przeprowadzania ich w trybie pokazowym bezpośrednio w zakładzie pracy lub miejscu zamieszkania sprawcy $^{57}$.

W trakcie postępowania organ administracji mógł dojść do przekonania, iż bardziej celowe z punktu widzenia efektów wychowawczych byłoby przekazanie sprawy społecznym organom wymiaru sprawiedliwości. Do ich kompetencji należała decyzja o przyjęciu sprawy do rozpoznania lub o pozostawieniu jej w gestii organów administracji ${ }^{58}$. Praktyczne znaczenie orzecznictwa sądów społecznych w dziedzinie wykroczeń porządkowych na tle całokształtu ich orzecznictwa było znikome. W przypadku komisji konfliktowych nie przekroczyło jednego procenta $^{59}$, natomiast w odniesieniu do komisji rozjemczych czterech procent ${ }^{60}$. Przyczyn tak nikłego udziału społecznych organów wymiaru sprawiedliwości w rozpoznawaniu spraw o wykroczenia porządkowe upatrywano w biernej postawie kierowników organów administracji państwowej, którzy nie byli skorzy do dzielenia się kompetencjami w zakresie orzecznictwa karno-administracyjnego, traktując je na zasadzie swoistego monopolu ${ }^{61}$.

Zakończenie postępowania karno-administracyjnego powinno nastąpić w ciągu miesiąca od jego wszczęcia przez organ orzekający, co wynikało z uproszczonego trybu tego postępowania na wzór procedury administracyjnej. Merytoryczne zakończenie sprawy karno-administracyjnej przybierało formę kary administracyjnej lub umorzenia postępowania. Warunki umorzenia obej-

${ }^{56}$ Jeżeli wykroczeniem porządkowym został wyrządzony znaczny uszczerbek i zachodziła potrzeba wymierzenia surowych środków karnych, to ze względów prewencji ogólnej zajmujący się orzecznictwem karno-administracyjnym urzędnik rady terenowej wyznaczał działający pod jego kierunkiem zespół orzekający, składający się z trzech obywateli. Powinni oni być fachowcami w danej dziedzinie, którzy przez aktywny udział w rozprawie mieli przyczynić się do wyjaśnienia sprawy oraz wydania orzeczenia wpływającego wychowawczo na osobowość sprawcy. Gesellschaftliche Kräfte im Oerdnungsstrafverfahren, „Neue Justiz” 1986, nr 4, s. 163.

${ }^{57}$ Ibidem.

58 W. Surkau, Übergabe von Ordnungswidrigkeitssachen an der gesellschaftliche Gericht, „Neue Justiz" 1984, nr 2, s. 68.

${ }^{59} \mathrm{~W}$ przypadku komisji konfliktowych stosunek liczby spraw o wykroczenia porządkowe do ogólnej liczby rozpoznanych spraw wynosił z reguły poniżej jednego procenta. W 1969 r. udział spraw o wykroczenia porządkowe wynosił 0,83\%, w 1975 0,63\%, a w 1980 r. 0,78\%. Rekordowy w działalności orzeczniczej komisji konfliktowych rok 1985 to zaledwie 0,84 \% rozpoznanych spraw o wykroczenia porządkowe. B. Schubel, Geschichte und Gegenwart..., s. 318-319.

${ }^{60} \mathrm{~W}$ całokształcie orzecznictwa komisji rozjemczych sprawy o wykroczenia porządkowe w $1969 \mathrm{r}$. stanowiły 1,22\%, a w 1975 1,07\%. W latach osiemdziesiątych udział spraw o wykroczenia porządkowe cechowała tendencja zwyżkowa, np. w 1984 r. sprawy te stanowiły 3,57\% ogółu rozpoznanych spraw, a w rekordowym pod tym względem 1987 r. 4 procent. H. A. Schönfeldt, Gesellschaftliche Gerichte in der DDR, w: Recht im Sozialismus, Band 2 - Justizpolitik, Frankfurt am Main 1999, s. 257.

${ }^{61}$ B. Schubel, Geschichte und Gegenwart..., s. 92-93. 
mowały szeroki wachlarz rozstrzygnięć organu orzekającego, od właściwego uniewinnienia, przez stwierdzenie negatywnych przesłanek procesowych, aż do niecelowości wymierzania kary. Stanowiło to konsekwencję braku skargowej i kontradyktoryjnej formy postępowania ${ }^{62}$. Orzeczenie wymierzające karę zapadało w formie tzw. nakazu karnego, od którego przysługiwało ukaranemu prawo wniesienia odwołania. Na podobieństwo procedury administracyjnej odwołanie wnosiło się za pośrednictwem organu, który rozstrzygał sprawę w pierwszej instancji celem rozważenia zmiany pierwotnego orzeczenia. Jeżeli organ ten uznał odwołanie za nieuzasadnione, to przekazywał sprawę organowi nadrzędnemu do ostatecznego rozstrzygnięcia. Organ odwoławczy obowiązywał zakaz obostrzenia kary, przy czym wobec braku oskarżyciela nie istniała możliwość założenia środka prawnego na niekorzyść osoby ukaranej ${ }^{63}$.

\section{Wnioski}

Historia prawa wykroczeń NRD to proces stopniowego wyodrębniania tej grupy czynów karalnych $\mathrm{z}$ obszaru prawa karnego w samodzielną dziedzinę spenalizowanych przez prawo zachowań. Ewolucja wykształconego w XIX w. niemieckiego systemu prawa karno-administracyjnego w duchu socjalistycznym wyrażała się w poddawaniu zawartych w kodeksie karnym i ustawach pozakodeksowych wykroczeń orzecznictwu Policji Ludowej, przy jednoczesnym pozbawieniu aparatu administracji państwowej kompetencji w tym zakresie. $\mathrm{W}$ to miejsce organy administracji publicznej otrzymały prawo stosowania sankcji wobec sprawców naruszeń przepisów porządkowych związanych z wykonywaniem przez te organy zadań państwowych. Opierając się na funkcjonującej w krajach „demokracji ludowej” materialnej definicji przestępstwa, traktowano naruszenia dyscypliny społecznej utrudniające pracę aparatu państwowego lub łamiące zasady współżycia społecznego jako czyny o znikomym stopniu szkodliwości. Wobec braku cech bezprawia kryminalnego nie uważano ich za przestępstwa. Ważną cechą wyróżniającą wykroczenia porządkowe było pozbawienie sprawcy możliwości kwestionowania orzeczenia organu administracji na drodze sądowej, gdyż ukaranemu przysługiwało wyłącznie prawo wniesienia odwołania do organu wyższego szczebla. To sprzeczne z założeniami niemieckiego systemu orzecznictwa karno-administracyjnego rozwiązanie będzie stopniowo rozszerzane na kolejne grupy wykroczeń związanych z funkcjonowaniem aparatu administracji państwowej.

\footnotetext{
${ }^{62}$ J. Śliwowski, B. Koch, Ustawa Niemieckiej Republiki Demokratycznej..., s. 93.

${ }^{63}$ W. Surkau, Verhütung ..., s. 145-150.
} 
Zwieńczeniem procesu wyodrębniania drobnych czynów karalnych w samodzielną grupę wykroczeń porządkowych było uchwalenie w 1968 r. OWG. Ustawa ta stanowiła nowe rozwiązanie w dziedzinie zwalczania wykroczeń na tle regulacji obowiązujących w innych krajach demokracji ludowej, odbiegając znacząco również od przyjętych w polskim ustawodawstwie wzorów i techniki legislacyjnej. OWG miała postać zbioru podstawowych zasad polityki zwalczania wykroczeń, przez co jej postanowienia cechował ramowy i wybitnie blankietowy charakter $^{64}$. Socjalistyczne założenie o wychowawczej roli orzecznictwa karno-administracyjnego $\mathrm{w}$ najszerszym zakresie próbowano zrealizować właśnie w NRD, gdyż OWG wyraźnie wysuwała na plan pierwszy wątek wychowawczy tego orzecznictwa. Prymat oddziaływania społeczno-wychowawczego stanowił klamrę spinającą w całość wykroczenia porządkowe i drugą grupę drobnych czynów karalnych, którymi były powstałe wskutek depenalizacji niektórych występków przewinienia. System kar stosowanych wobec sprawców tych dwóch rodzajów wykroczeń był na tle rozwiązań polskich zdecydowanie łagodniejszy, gdyż najsurowszą karą była grzywna, nie przewidziano natomiast kary aresztu w żadnej postaci. Nie występowała także kara zasadnicza, która byłaby surowsza od grzywny i stanowiłaby odpowiednik polskiej kary ograniczenia wolności. Ustawodawca niemiecki położył większy nacisk na społeczno-wychowawcze formy oddziaływania wobec sprawców wykroczeń niż to miało miejsce w Polsce Ludowej. Wyrazem tego była duża swoboda oceny poszczególnych przypadków w zależności od okoliczności i osoby sprawcy oraz ograniczenie represji na rzecz stosowania dodatkowych środków karno-porządkowych ${ }^{65}$. Innym przejawem oddziaływania społeczno-wychowawczego było przekazanie spraw o przewinienia orzecznictwu sądów społecznych, jednak nie uczyniono tego w przypadku najczęściej popełnianych przewinień na szkodę własności społecznej lub indywidualnej. Były one zagrożone grzywną wymierzaną przez organy Policji Ludowej. Ukarany w drodze tzw. policyjnego nakazu karnego mógł zgłosić żądanie rozpatrzenia sprawy przez sąd powszechny. Uprawnienie to przysługiwało także ukaranym przez sądy społeczne w sprawach o pozostałe przewinienia, co stanowiło skromny wyraz tradycji niemieckiego systemu orzecznictwa w sprawach o wykroczenia. Do tradycji tej nie nawiązano w przypadku wykroczeń porządkowych poddanych orzecznictwu organów administracji państwowej, wymierzających kary w trybie zbliżonym do postępowania administracyjnego. Orzecznictwo $\mathrm{w}$ sprawach o wykroczenia porządkowe zostało przyporządkowane instancjom administracyjnym w zależności od rodzaju wykroczenia; postępowanie karno-administracyjne nie posiadało formy skargowej i kontradyktoryjnej. Była to istotna różnica na tle rozwiązań polskich, gdzie w ramach terenowego aparatu

${ }^{64}$ J. Śliwowski, B. Koch, Ustawa Niemieckiej Republiki Demokratycznej..., s. 95.

${ }^{65}$ N. Debski, Das polnische...., s. 106. 
rad narodowych funkcjonowały kolegia do spraw wykroczeń, wyspecjalizowane organy quasi-sądowe o składzie społecznym. Postępowanie karno-administracyjne Polski Ludowej oparte było na zasadach kontradyktoryjności i skargowości, chociaż przewidywało możliwość wymierzania kar przez organy administracji $\mathrm{w}$ drodze uproszczonego trybu mandatowego ${ }^{66}$.

Wprowadzony w 1968 r. w ramach kompleksowej reformy prawa karnego NRD model orzecznictwa karno-administracyjnego stanowił nowatorskie rozwiązanie w zakresie zwalczania wykroczeń, które miało odpowiadać specyfice stosunków społecznych i mentalności wschodnioniemieckiej. Zakorzenione $\mathrm{w}$ narodzie niemieckim poczucie posłuszeństwa wobec władzy, połączone $\mathrm{z}$ wielowiekową tradycją przestrzegania prawa, skutkowało akceptacją przez społeczeństwo NRD socjalistycznego porządku prawnego. W takich warunkach kierownictwo SED uznało za celowe stopniowe łagodzenie ostrza represji karno-administracyjnej na rzecz środków oddziaływania wychowawczego, ukierunkowanych na wdrażanie sprawców wykroczeń do przestrzegania dyscypliny społecznej. Leżąca u podstaw stosowania środków społeczno-wychowawczych w NRD teoria, iż „w miarę wzrostu świadomości społecznej znaczenie kar o przewadze elementów represji będzie malało, a dominujący wpływ w tym zakresie będą miały środki oddziaływania wychowawczego"67, w przypadku Polski nie miała szans skutecznej realizacji. Nasze społeczeństwo nigdy w pełni nie zaakceptowało systemu komunistycznego, stąd władza próbowała nakłonić obywateli do przestrzegania socjalistycznego prawa za pomocą środków karno-administracyjnych o charakterze represyjnym.

${ }^{66}$ J. Skupiński, Prawo o wykroczeniach..., s. 26-27.

${ }^{67}$ B. Adamiak, Ewolucja systemu kar w orzecznictwie w sprawie wykroczeń w PRL, „Acta Universitatis Wratislaviensis, Przegląd Prawa i Administracji VIII", Wrocław 1976, s. 122. 